\title{
MICROBIAL POPULATION IN PHYLLOSPHERE OF MANGROVES GROW IN DIFFERENT SALINITY ZONES OF BHITARKANIKA (INDIA)
}

\author{
Nibha GUPTA ${ }^{1 *}$, Srilekha MISHRA ${ }^{1}$ and Uday Chand BASAK ${ }^{2}$ \\ ${ }^{1}$ Microbiology Laboratory, Division of Biotechnology, \\ Regional Plant Resource Centre, Bhubaneswar 751015 (Orissa) \\ ${ }^{2}$ Division of Taxonomy and Conservation, \\ Regional Plant Resource Centre, Bhubaneswar 751015 (Orissa) \\ *Corresponding author: nguc2003@yahoo.co.in
}

Recibido el 15 de junio de 2008, aceptado para su publicación el 25 de marzo de 2009

Publicado "on line" en mayo de 2009

\begin{abstract}
SUMMARY. Microbial population in phyllosphere of mangroves grow in different salinity zones of Bhitarkanika (India). The bacterial and fungal populations in phyllosphere of mangrove plants were investigated in order to evaluate differences in their occurrence associated with host species. Study sites included relatively undisturbed and purely mangrove area that were selected for sampling from both the low and intermediate salinity zones. Microbial population count was analyzed in 11 and 14 different and/or similar plant species from these two salinity zones. The maximum microbial population was observed in phyllosphere of low salinity zone. However, Crinum defixum L. was found to be most populated with bacteria among all other phyllosphere plant samples tested.
\end{abstract}

Key words. Mangrove, bacteria, fungi, salinity, Bhitarkanika.

RESUMEN. Poblaciones microbianas de las hojas de manglares que crecen en zonas de diferente salinidad de Bhitarkanika (India). Se estudiaron las poblaciones de bacterias y hongos que se desarrollan sobre las hojas de manglares con el objeto de evaluar si había diferencias entre las especies hospedadoras. El estudio incluía manglares de áreas no alteradas, y se escogieron zonas que representasen valores de salinidad bajo (11 especies) y media (14 especies), respectivamente. El valor más alto de las poblaciones microbianas se detectó en hojas de manglares de la zona de baja salinidad, pero en la zona de salinidad media Crinum defixum L. fue la especie hospedadora con los niveles más altos de poblaciones bacterianas.

Palabras clave. Manglares, bacterias, hongos, salinidad, Bhitarkanika.

\section{INTRODUCTION}

Mangrove ecosystems are situated at the inter-phase between marine and terrestrial environment which is highly productive providing nutrients to surrounding microbiota (Alongi, 2005). In response, microbial system participate in biomineralization of organic 
matter and biotransformation of minerals. Several foliar fungi and bacteria are reported for their occurrence and beneficial activity in mangrove ecosystem (Ananda \& Sridhar, 2004; Kathiresan \& Selvam, 2006). Bhitarkanika is second largest mangrove ecosystem in India. A survey has been made towards the population status of bacteria and fungi associated with the phyllopsphere of different mangrove plants.

\section{MATERIALS AND METHODS}

Mangroves of Bhitarkanika, Orissa $\left(20^{\circ} 30^{\prime}-20^{\circ} 50^{\prime} \mathrm{N}, 86^{\circ} 45^{\prime}-87^{\circ} 10^{\prime} \mathrm{E}\right)$ occupy a littoral habitat, characterized almost invariably by salt or brackish water and coastal silt exposed to daily tidal inundation with a continuously changing salinity and represented by tree mangroves from the genera Avicennia, Aegiceras, Bruguiera, Ceriops, Excoecaria, Heritiera, Kandelia, Rhizophora and Sonneratia. However, there is no available data on the status of microbial population associated with phyllosphere of tree mangroves of Bhitarkanika.

The sampling zone was such a habitat where high spring tides inundate occasionally. The soil reaction changes from alkaline to moderately acidic condition and the zone is mainly colonized by Acanthus ilicifolius L., Acrostichum aureum L., Aegiceras corniculatum Blanco, Aglaia cucullata (Roxb.) Pellegr., Avicennia officinalis L., Bruguiera gymnorrhiza (L.) Lam., Bruguiera parviflora (Roxb.) Wight \& Arn. ex Griff., Brownlowia tersa (L.) Kosterm., Dalbergia spinosa Roxb., Derris heterophyla (Wild) Back, Excoecaria agallocha L., Heritiera fomes Buch.-Ham., Kandelia candel (L.) Druce and Sonneratia caseolaris (L.) Engl. It was covered four different locations i.e. Bhrahmani river, Khola mouth, Khola and confluence point of Khola and Bhitarkanika.

The mid tidal zone along the creeks is greatly influenced by intermediate salinity and tidal action and largely colonized by $A$. ilicifolius, A. corniculatum, A. cucullata, A. officinalis, Caesalpinia crista L., D. heterophyla, E. agallocha, H. fomes, Sesuvium portulacastrum (L.) L., S. caseolaris and Tamarix troupii Hole. It was covered five locations i.e. Balizore, Brahmamari creek, Dangmal, Mahishmari creek and confluence point of Balizore and Khola.

The above mentioned locations were visited through country boat and plant samples were collected in pre-sterilized sample containers. Total 9 and 14 plant samples in triplicate were collected from intermediate and low salinity zones, respectively. It was identified by one of our author (UCB) on the spot and brought to the laboratory for further studies.

The leaf samples were thoroughly washed with sterile distilled water prior to inoculation. The surface sterilization of leaves were made through $0.1 \% \mathrm{HgCl}_{2}$ for $30 \mathrm{~s}$ and again rewashed through flowing sterile distilled water for $10 \mathrm{~min}$. The leaves were cut into $5 \mathrm{~mm}$ disc through cork borer. Five numbers of leaf discs of each sample in dipped into $10 \mathrm{ml}$ of sterile distilled water and subjected to serial dilution after vigorous shaking. The $10^{-3}$ diluted samples were inoculated on marine agar and potato dextrose agar and incubated at $30^{\circ} \mathrm{C}$ and $37^{\circ} \mathrm{C}$ for the 7 days to procure bacterial and fungal colonies (Aneja, 1993). Bacterial colonies on Marine agar (Hi Media) obtained through serial dilution technique were counted by colony counter. The total population of bacteria and fungi were calculated and presented in terms of number per square centimeter leaf area. Finally, data were analyzed for variance (one way ANOVA) among and between the bacteria and fungi used in this study (Sokal \& Rohlf, 1995).

\section{RESULTS}

The data recorded for the population count in phyllosphere of different mangrove plant 


\begin{tabular}{lcccc}
\hline Mangrove species & \multicolumn{2}{c}{ No. of bacteria $\left(\times 10^{3}\right)$} & \multicolumn{2}{c}{ No. of fungi $\left(\times 10^{3}\right)$} \\
\hline & Mean & SD & Mean & SD \\
\cline { 2 - 5 } Acanthus ilicifolius & 12.8 & 8.8 & 0.8 & 0.3 \\
Aegiceras corniculatum & 15.2 & 2.6 & 1.8 & 1.2 \\
Avicennia officinalis & 4.7 & 1.4 & 0.3 & 0.2 \\
Caesalpinia crista & 17.1 & 4.5 & $3.4^{*}$ & 0.8 \\
Crinum defixum & $528.3^{*}$ & 83.4 & 0.6 & 0.2 \\
Derris heterophylla & 12.6 & 4.3 & 0.3 & 0.2 \\
Excoecaria agallocha & 23.5 & 12.5 & 0.3 & 0.2 \\
Heritiera fomes & 2.3 & 0.2 & 0.4 & 0.2 \\
Sesuvium portulacastrum & 3.2 & 0.2 & 0.8 & 0.4 \\
Sonneratia caseolaris & 17.3 & 4.5 & 0.8 & 0.3 \\
Tamarix troupii & 11.0 & 1.4 & $3.2^{*}$ & 0.4 \\
\hline
\end{tabular}

Table 1. Microbial population per $\mathrm{cm}^{2}$ in phyllopsphere (mean and SD) of mangroves grow in intermediate salinity zone of Bhitarkanika (*, significant at $P<0.001, n=3$ ).

species exhibited variation among different plant systems with respect to their association with microbial system. The mangrove plants of intermediate salinity zone were found to be populated with less number of bacteria and fungi as compare to low salinity zone (tabs. 1, 2). However, the leaves of $C$. defixum collected from intermediate salinity zone have shown highest bacterial population $\left(528.3 \times 10^{3} \mathrm{~cm}^{-}\right.$ $\left.{ }^{2}\right)$ (tab. 1). Other plant species have exhibited similar bacterial population ranged between 11$17 \times 10^{3} \mathrm{~cm}^{-2}$ except in $A$. officinalis, $H$. fomes and $S$. portulacastrum that had low population count of bacteria in their phyllosphere (tab. 1). A similar pattern of fungal population was observed in phyllosphere of C. crista $\left(3.4 \times 10^{3}\right.$ $\left.\mathrm{cm}^{-2}\right)$ and T. troupii $\left(3.2 \times 10^{3} \mathrm{~cm}^{-2}\right)($ tab. 1).

The microbial population of mangrove plants of low salinity zone was found at higher level (tab. 2). Almost all plant species studied have more or less similar range except $K$. candel and $B$. tersa that exhibited higher bacterial population i.e. $167.7 \times 10^{3} \mathrm{~cm}^{-2}$ and $71.6 \times 10^{3}$ $\mathrm{cm}^{-2}$, respectively (tab. 2). The fungal population in leaves of $A$. officinalis, B. gymnorrhiza, $B$. parviflora and $D$. heterophylla were found to be higher in the low salinity zones (tab. 2).

Among the phyllosphere of mangrove species tested, the bacterial and fungal populations in both the intermediate and low salinity zones were found significantly variable at $0.05 \%$ level. Analysis of variance for bacterial population of $C$. defixum collected from intermediate salinity zone revealed the significant variation (tab. 1). On the other hand, the rest of the plants exhibited almost similar pattern of bacterial population. Similarly, the fungal population was significantly higher in T. troupii and C. crista as compared to other plants obtained from intermediate salinity zone. A wide level of variation was found through the analysis of variance for bacterial population in phyllosphere of mangrove species of low salinity zones among them all showed significant variations $(P<0.001)$ and highest number of bacterial colonies were observed in $K$. candel and B. tersa. Data recorded for fungal population in mangrove plants of low salinity zones were also subjected to statistical analysis. It was observed that $A$. officinalis, $B$. gymnorrhiza, B. parviflora and $D$. heterophyla exhibited significantly higher but similar pattern of fungal population.

Seven plant species were found common in both the salinity zone. It was observed that A. ilicifolius, A. corniculatum, A. officinalis, $D$. heterophylla and $H$. fomes were found to be less populated with bacteria in intermediate than low salinity where as E. agallocha and $S$. caseolaris had similar bacterial population in 


\begin{tabular}{lcccc}
\hline Mangrove species & \multicolumn{2}{c}{ No. of bacteria $\left(\times 10^{3}\right)$} & \multicolumn{2}{c}{ No. of fungi $\left(\times 10^{3}\right)$} \\
\hline & Mean & SD & Mean & SD \\
\cline { 2 - 5 } Acanthus ilicifolus & 18.7 & 2.5 & 0.9 & 0.4 \\
Acrostichum aureum & 32.0 & 15.4 & 0.5 & 0.0 \\
Aegiceras corniculatum & 28.6 & 12.6 & 1.7 & 0.5 \\
Aglaia cucullata & 8.1 & 7.6 & 2.0 & 0.5 \\
Avicennia officinalis & 18.9 & 1.9 & $3.5^{*}$ & 0.3 \\
Bruguiera gymnorrhiza & 27.4 & 3.5 & $3.4^{*}$ & 0.8 \\
Bruguiera parviflora & 22.3 & 3.2 & $3.5^{*}$ & 0.5 \\
Brwonloia tersa & 71.6 & 64.3 & 0.8 & 0.3 \\
Dalbergia spinosa & 39.7 & 28.0 & 0.4 & 0.2 \\
Derris heterophylla & 28.0 & 4.7 & $3.9 *$ & 0.8 \\
Excoecaria agallocha & 23.4 & 2.3 & 2.2 & 0.6 \\
Heritiera fomes & 18.0 & 2.3 & 0.5 & 0.3 \\
Kandelia candel & $167.7 *$ & 43.6 & 0.3 & 0.2 \\
Sonneratia caseolaris & 11.4 & 7.6 & 1.0 & 0.3 \\
\hline
\end{tabular}

Table 2. Microbial population per $\mathrm{cm}^{2}$ in phyllopsphere of mangroves grow in low salinity zone of Bhitarkanika (*, significant at $P<0.001, n=3$ ).

both the salinity zones (tab.s 1, 2). Similarly, A. officinalis, D. heterophylla and E. agallocha have poor fungal population in intermediate salinity zone where as it was quite higher in the same plants found in low salinity area (tabs. 1, 2).

\section{DISCUSSION}

Many bacteria and fungi are reported from different mangrove ecosystem and found to be responsible for the biodegradation of organic wastes developed through mangrove litter fall. The present study on the occurrence and distribution of bacterial and fungal population in phyllosphere of different mangrove species frequency of fungal occurrence was has also supported with the observation on microbial communities of Avicennia sp. by Sarma et al. (2001). Our observations are also corroborated with the report on diversity of fungal colonies on B. gymnorrhiza (Maria \& Sridhar, 2002).

The poor colonization of fungi on mangrove plants of intermediate salinity zone may be due to salt excretion in leaves which serve as an important defense against fungal attack and /or colonization (Gilbert et al.,
2002). Overall, more number of bacteria and fungi were found in low salinity zone. The difference in occurrence of bacteria and fungi in different salinity zones indicates that marine microbes have a significant role to play in local mangrove communities (Steinke \& Lubke, 2003). It is quite apparent from this study that no mangrove phyllosphere was populated with both bacteria and fungi with equal strength. Crinum defixum was populated heavily with bacteria where as fungal population recorded in this plant was very poor. Similarly, very poor population count of bacteria was observed in $T$. troupii while higher fungal population colonized it. These observatory facts indicated the biological competition among the different groups of microbial communities. Compared to studies on microbial diversity in different ecosystem, the study of microbial system in mangrove is in its preliminary phase. In this case, the information concluded by the present study may be helpful in sampling of research materials for various objectives.

ACKNOWLEDGMENTS. Authors are thankful to Ministry of Environment and Forests Govt. of India for financial assistance through project no. 22/7/2003-CS/BR to NG. 


\section{REFERENCES}

ALONGI, D. M. -2005- Mangrove microbe soil interactions. Coastal and Estuarine Studies 60: 85-103.

ANANDA, K. \& SRIDHAR, K. R. -2004- Diversity of filamentous fungi on decomposing leaf and woody litter of mangrove forests in the southwest coast of India. Current Science 87: 1431-1437.

ANEJA, K.R. -2003- Experiments in Microbiology, Plant Pathology and Tissue Culture. Wishwa Prakashan, Wiley Eastern Ltd.

GILBERT, G. S., CHANG, N. M. \& ROJAS, E. -2002- Fungal diversity and plant disease in mangrove forests: salt excretion as a possible defense mechanisms. Oecologia 132: 278-285.

KATHIRESAN, K. \& SELVAM, M. M. -2006-
Evaluation of beneficial bacteria from mangrove soil. Botanica Marina 49: 86-88.

MARIA, G. L. \& SRIDHAR, K. R. -2002- Richness and diversity of filamentous fungi on woody litter of mangrove along the east coast of India. Current Science 83: 1573-1577.

SARMA, V. V, HYDE, K. D. \& VITTAL, B. P. R. -2001- Frequency of occurrence of mangrove fungi from the east coast of India. Hydrobiologia 455: 41-53.

STEINKE, T. D. \& LUBKE, R. A. -2003-Arenicolous marine fungi from Southern Africa. South African Journal of Botany 69: 540-545.

SOKAL, R. R. \& ROHLF, J. F. -1995- Biometry. The Principles and Practice of Statistics in Biological Research ( ${ }^{\text {rd }}$ ed.). W.H. Freeman and Company, New York. 